\title{
PERBANDINGAN BEBERAPA METODE PEMBUATAN METIL ESTER DALAM ANALISA ASAM LEMAK DARI VIRGIN COCONUT OIL (VCO)
}

\author{
Julius Pontoh $^{1)}$ dan Lita Makasoe ${ }^{1)}$ \\ ${ }^{1)}$ Program Studi Kimia FMIPA Universitas Sam Ratulangi, Manado 95115 \\ e-mail: pontohjulius@yahoo.com
}

\begin{abstract}
ABSTRAK
Transesterifikasi merupakan metode awal dalam analisa asam asam lemak dalan minyak dengan teknik kromatografi gas. Tujuan dari penelitian ini adalah untuk mempelajari efisiensi diantara berbagai metode transesterifikasi dalam analisa asam asam lemak dalam minyak kelapa murni. Metode yang dipelajari meliputi transesterifikasi asam dan basa menurut Christie (1993), transesterifikasi asam dan basa menurut Laureles, at al. (2002) dan trasesterifikasi menurut IUPAC (1997). Hasil penelitian menunjukan bahwa diantara metode yang dipelajari hanya memberikan sedikit perbedaan waktu retensi dari asam asam lemak dengan berbagai erlakuan metode transesterifikasi. Metode IUPAC (1997) memberikan luas puncak yang lebih besar dari anatara metode yang dipelajari. Transesterifikasi basa dengan metode Christie (1992) memberikan persentasi luas area tertinggi untuk asam laurat, diikuti dengan transesterifikasi asam dengan metode Laureles, et al., 2002), tetapi untuk persentasi luas puncak dari asam kaprilat dan kaprat metode IUPAC (1997) menghasilkan persentasi luas luncak yang lebih besar. Dengan demikian, untuk analisa asam asam lemak dalam VCO, metode IUPAC (1997) adalah yang terbaik.
\end{abstract}

Kata kunci: metil ester, VCO

\section{COMPARISON OF SOME METHODS IN MAKING METHYL ESTER OF FATTY ACID ANALYSIS FROM VIRGIN COCONUT OIL (VCO)}

\begin{abstract}
Transeterification is always the first step in analysis of fatty acid using gas chromatographic method. The goal of this research is to study the efisiency of the derivative methods for fatty acid analysis. The methods to be studied including acid and base transesterification (Christie, 1993), acid and base transesterification (Laureles, et al., 2002) and esterification (IUPAC, 1997). The results show that among the methods there are only slightly different in retention time. The IUPAC (1997) method showed higher peak area among the methods tested. The base transeterification by Christie (1993) produce the highest percentage peak area for the lauric acid followed by acid tranesterification by Laureles, et al. (2002). But for caprylic and capric acids, the esterification by IUPAC (1997) produce higher percentage of peak areas. Therefore, for the purpose of VCO's fatty acid analysis, the IUPAC method should be the choice.
\end{abstract}

Keywords: methyl ester, VCO

\section{PENDAHULUAN}

Kelapa sebagai salah satu kekayaan hayati Indonesia telah berabad-abad yang lalu dimanfaatkan untuk memenuhi berbagai kebutuhan, baik sebagai sumber makanan, obat-obatan maupun industri. Pada masyarakat Indonesia, buah kelapa banyak digunakan dalam kehidupan sehari-hari, baik di pedesaan maupun di perkotaan. Terutama daging buahnya dapat dipakai sebagai bahan baku untuk menghasilkan kopra, minyak kelapa, santan dan kelapa parut.

$$
\text { Virgin Coconut Oil (VCO) }
$$
merupakan hasil olahan dari daging buah kelapa segar (non kopra), dalam pengolahannya tidak melalui proses kimiawi dan tidak menggunakan pemanasan tinggi 
hingga minyak yang dihasilkan berwarna bening (jernih) dan beraroma khas kelapa. Menurut standar internasional yang dikeluarkan oleh Asian Pacific Coconut Community (APCC, 2004) bahwa kandungan asam lauratnya mencapai 43-53\%, kandungan asam lemak bebas sangat rendah yaitu $\leq 0,5 \%$ serta kadar airnya mencapai 0,1-0,5\%. Komposisi asam lemak tertinggi dalam minyak kelapa murni adalah asam laurat yang berfungsi dapat memberi gizi serta melindungi tubuh dari penyakit menular dan penyakit degeneratif (Sutarmi, 2005).

Komposisi asam lemak berbeda-beda sesuai dengan sumber minyak itu. Komposisi asam lemak dalam daging buah kelapa terdiri dari asam lemak jenuh yaitu asam kaproat $(0,5 \%)$, asam kaprilat $(8,0 \%)$, asam kaprat $(6,4 \%)$, asam laurat $(48,5 \%)$, asam miristat $(17,6 \%)$, asam palmitat $(8,4 \%)$, asam stearat $(2,5 \%)$ dan asam lemak tidak jenuh yaitu asam oleat $(6,5 \%)$, asam linoleat $(1,5 \%)$ (Zapsalis dan Beck, 1985).

Proses esterifikasi bertujuan untuk mengubah asam-asam lemak dari trigliserida dalam bentuk metil ester atau etil ester kemudian diikuti dengan fraksinasi yang dilakukan dengan kromatografi gas. Menurut Christie (1993), pembuatan metil ester asam lemak dari minyak dapat dilakukan melalui proses esterifikasi atau transesterifikasi dengan katalis asam misalnya $\mathrm{H}_{2} \mathrm{SO}_{4}$ maupun katalis basa misalnya kalium metoksida. Metode yang digunakan harus sesuai dengan karakteristik asam-asam lemak. Untuk analisa asam lemak rantai pendek harus mendapat perlakuan yang khusus, karena asam lemak tersebut mudah menguap selama proses esterifikasi dan mudah larut dalam air. Misalnya dalam susu terdapat asam lemak rantai pendek sehingga dianjurkan menggunakan metode esterifikasi dengan katalis asam misalnya $\mathrm{HCl}$ ( Christie, 1993).

Sampai sekarang metode pembuatan ester telah banyak dikembangkan oleh Christie (1993), Laureles (2002) dan International Union of Pure and Applied Chemistry (IUPAC, yang diterapkan oleh Institut Pertanian Bogor, IPB). Namun demikian, metode-metode tersebut diterapkan kembali ke VCO untuk melihat metode mana yang paling baik dalam menganalisa metil ester khususnya ester dari kaproat dan kaprilat, metil ester kaproat dan kaprilat digunakan sebagai indikator untuk melihat metode yang terbaik, karena asam kaproat dan kaprilat dalam minyak kelapa sangat rendah, masing-masing 0,5 \% dan 8,0 \% (Zapsalis dan Beck, 1985).

Berdasarkan uraian di atas bahwa minyak kelapa mengandung asam lemak rantai pendek yaitu $0,5 \%$ asam kaproat dan $8,0 \%$ asam kaprilat yang bersifat mudah menguap dan mudah larut dalam air, sehingga analisa dari minyak kelapa khususnya VCO perlu diperlakukan secara khusus.

\section{Tujuan Penelitian}

Adapun tujuan yang ingin dicapai yaitu untuk mengetahui metode pembuatan metil ester yang terbaik untuk analisa asam lemak pada VCO khususnya asam kaproat dan asam kaprilat.

\section{METODOLOGI PENELITIAN}

\section{Bahan Dan Alat}

Bahan-bahan yang digunakan dalam penelitian ini adalah VCO komersil (Nyiur Melambai), $\mathrm{NaOH}, \mathrm{H}_{2} \mathrm{SO}_{4}$ p.a, metanol p.a, n-heksana, $\mathrm{NaCl}, \quad \mathrm{Na}_{2} \mathrm{SO}_{4}$ anhidrous, petroleum eter, kertas saring, aquades, aluminium foil. Alat-alat yang digunakan antara lain alat-alat gelas laboratorium, neraca analitik, karet penghisap, magnet bar, termometer, satu set alat refluks, satu set alat destilasi, hot plate, pipet mohr, corong pisah.

\section{Pembuatan Sampel}

\section{Transesterifikasi asam (Christie, 1993)}

Ke dalam labu leher tiga kapasitas $250 \mathrm{~mL}$ dimasukkan $25 \mathrm{~g}$ VCO sambil diaduk dengan batang pengaduk magnetik. Sebanyak $5 \mathrm{~mL} \mathrm{H}_{2} \mathrm{SO}_{4}$ dilarutkan dalam 100 $\mathrm{mL}$ metanol kemudian campuran larutan ini melalui corong penetes ditambahkan tetes demi tetes ke dalam VCO. Selanjutnya larutan direfluks selama 10 jam dengan pemanasan pada suhu $65{ }^{\circ} \mathrm{C}$. Larutan hasil refluks kemudian diekstraksi dengan petroleum eter dan aquades. Fase organik yang diperoleh ditambahkan $\mathrm{Na}_{2} \mathrm{SO}_{4}$ anhidrous kemudian disaring. Filtrat yang diperoleh selanjutnya diuapkan untuk menghilangkan pelarut. Residunya merupakan hasil metil ester asam lemak 
kemudian dianalisis dengan menggunakan kromatografi gas.

\section{Transesterifikasi basa (Christie, 1993)}

Ke dalam labu leher tiga kapasitas $250 \mathrm{~mL}$ dimasukkan $25 \mathrm{~g}$ VCO sambil diaduk dengan batang pengaduk magnetik. Sebanyak $5 \mathrm{~g} \mathrm{NaOH}$ dilarutkan dalam 100 $\mathrm{mL}$ metanol kemudian campuran larutan ini melalui corong penetes ditambahkan tetes demi tetes ke dalam VCO. Selanjutnya larutan direfluks selama 10 jam dengan pemanasan pada suhu $65{ }^{\circ} \mathrm{C}$. Larutan hasil refluks kemudian diekstraksi dengan petroleum eter dan aquades. Fase organik yang diperoleh ditambahkan $\mathrm{Na}_{2} \mathrm{SO}_{4}$ anhidrous kemudian disaring. Filtrat yang diperoleh selanjutnya diuapkan untuk menghilangkan pelarut. Residunya merupakan hasil metil ester asam lemak kemudian dianalisis dengan menggunakan kromatografi gas.

\section{Transesterifikasi asam (Laureles, 2002)}

Sebanyak $2 \mathrm{~mL}$ n-heksana ditambahkan dalam $0,1 \mathrm{~g}$ VCO kocok hingga bercampur. Ditambahkan metanolik $\mathrm{H}_{2} \mathrm{SO}_{4}$ sebanyak $0,4 \mathrm{~mL}$ ke dalam VCO kemudian dikocok selama 10 detik. Kemudian campuran larutan ditempatkan dalam water bath yang telah diukur suhunya yaitu $50{ }^{\circ} \mathrm{C}$ selama 1 menit dan dikocok selama 10 detik. Selanjutnya ditambahkan metanolik $\mathrm{NaOH}$ $0,4 \mathrm{~mL}$ dan dikocok beberapa detik hingga bercampur. Campuran larutan akan terbentuk dua lapisan, lapisan metil ester asam lemak dipisahkan kemudian dianalisis dengan menggunakan kromatografi gas.

\section{Transesterifikasi basa (Laureles, 2002)}

Sebanyak $2 \mathrm{~mL}$ n-heksana ditambahkan dalam $0,1 \mathrm{~g}$ VCO kocok hingga bercampur. Tambahkan metanolik $\mathrm{NaOH}$ sebanyak $0,4 \mathrm{~mL}$ ke dalam VCO kemudian dikocok selama 10 detik. Kemudian campuran larutan ditempatkan dalam water bath yang telah diukur suhunya yaitu $50{ }^{\circ} \mathrm{C}$ selama 1 menit dan kocok selama 10 detik. Selanjutnya ditambahkan metanolik $\mathrm{H}_{2} \mathrm{SO}_{4}$ $0,4 \mathrm{~mL}$ dan dikocok selama beberapa detik hingga bercampur. Campuran larutan akan terbentuk dua lapisan, lapisan metil ester asam lemak dipisahkan kemudian dianalisis dengan menggunakan kromatografi gas.

\section{Esterifikasi (IUPAC, 1987 dikerjakan oleh Lab. Kimia Organik IPB)}

Kedalam 0,1 g VCO ditambahkan nheksana $1 \mathrm{~mL}$ kemudian divortex dan ditambahkan $\mathrm{NaOH}$ 1,5 $\mathrm{mL}$. Setelah itu dipanaskan pada suhu $80{ }^{\circ} \mathrm{C}$ selama 5 menit kemudian didinginkan. Selanjutnya ditambahkan $\mathrm{BF}_{3}$ dalam metanol sebanyak 2 $\mathrm{mL}$ serta dipanaskan pada suhu $80{ }^{\circ} \mathrm{C}$ selama 25 menit. Kemudian didinginkan dan ditambahkan berturut-turut n-heksana $1,5 \mathrm{~mL}$ dan $3 \mathrm{~mL}$ larutan $\mathrm{NaCl}$ jenuh. Diambil lapisan atas, ditambahkan $\mathrm{Na}_{2} \mathrm{SO}_{4}$ anhidrous, disaring dan siap disuntikkan pada alat kromatografi gas.

\section{Analisa Sampel dengan Kromatografi Gas}

\begin{tabular}{lll}
\multicolumn{1}{c}{ Sampel } & \multicolumn{1}{c}{ dianalisa } & dengan \\
kromatografi & gas dengan & kondisi \\
sebagaimana dibawah ini. &
\end{tabular}

$\begin{array}{ll}\text { Gas pembawa } & : \text { He } \\ \text { Kolom } & : \text { Kapiler DB 23 } \\ & (90 \% \text { bis sianopropil dan } \\ & 10 \% \text { fenilsiano propil } \\ \text { Panjang kolom } & \text { Polisiloxane } \\ \text { Suhu awal } & : 50 \mathrm{~m} \\ \text { Suhu akhir } & : 120^{\circ} \mathrm{C} \\ \text { Jenis detektor } & : 230^{\circ} \mathrm{C} \\ & : \text { FID }\end{array}$

\section{HASIL DAN PEMBAHASAN}

\section{Kromatogram Metil Ester Asam Lemak VCO}

Dari gambar kromatogram (Gambar 1) terlihat bahwa asam-asam lemak telah ditentukan dengan menggunakan larutan standar.

Terdapat beberapa puncak yang berhubungan dengan masing-masing asam lemak, asam stearat dan oleat sedikit berhimpit namun demikian masih mempunyai resolusi yang baik. 


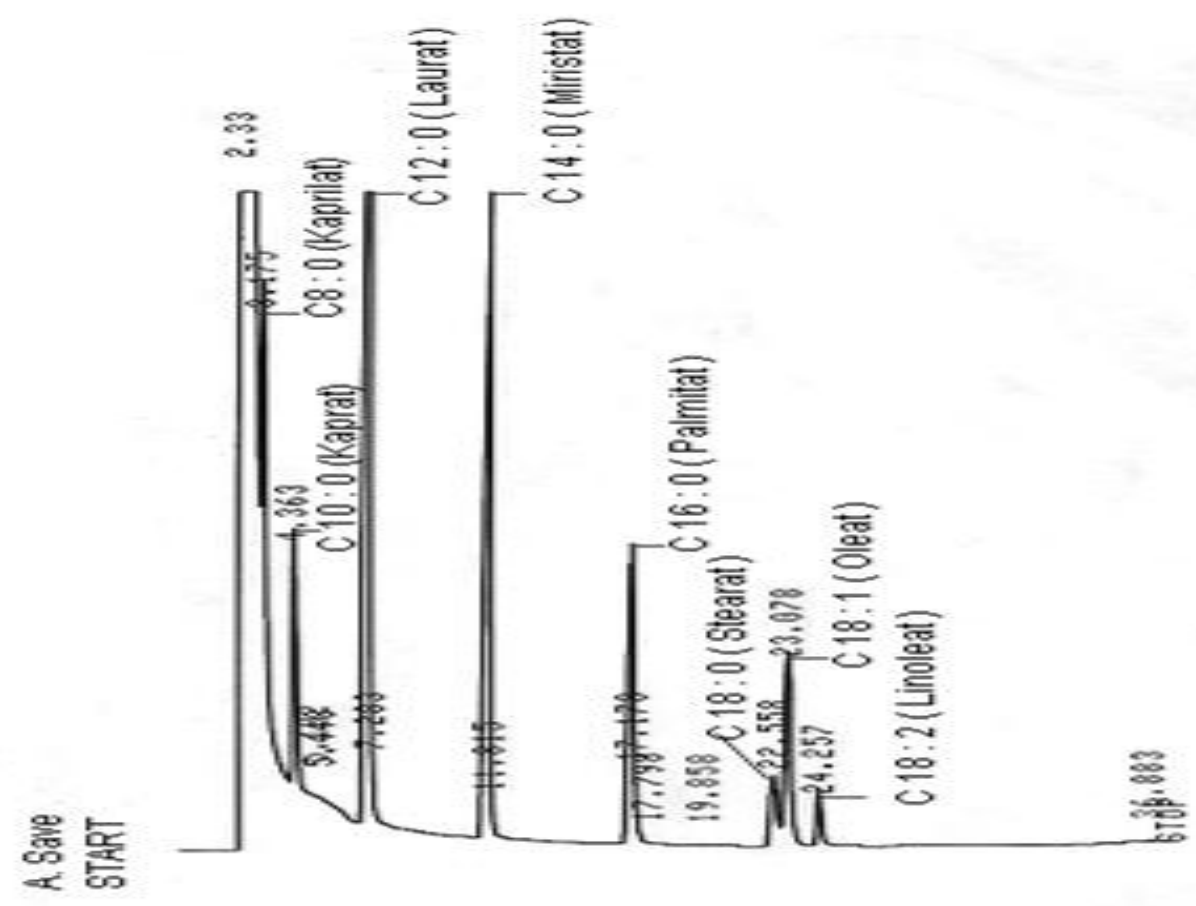

Gambar 1. Contoh kromatogram dengan menggunakan asam lemak standar untuk penentuan puncak berdasarkan pada waktu retensi pada metode transesterifikasi asam (Laureles, 2002) dari minyak kelapa murni (VCO).

Tabel 1. Waktu retensi metil ester asam lemak VCO dari berbagai metode.

\begin{tabular}{|c|c|c|c|c|c|}
\hline \multirow{3}{*}{ Asam lemak } & \multicolumn{5}{|c|}{ Waktu retensi } \\
\hline & \multicolumn{2}{|c|}{$\begin{array}{l}\text { Transesterifikasi } \\
\text { 1993) }\end{array}$} & \multicolumn{2}{|c|}{$\begin{array}{l}\text { Transesterifikasi (Laureles, } \\
\text { 2002) }\end{array}$} & \multirow{2}{*}{$\begin{array}{l}\text { Esterifikas } \\
\text { (IUPAC, } \\
\text { 1987) }\end{array}$} \\
\hline & Asam & Basa & Asam & Basa & \\
\hline Kaprilat(C8) & 3,1 & 3,1 & 3,1 & 3,1 & 3,1 \\
\hline Kaprat(C10) & 4,3 & 4,3 & 4,3 & 4,3 & 4,3 \\
\hline Laurat(C12) & 7,3 & 7,3 & 7,2 & 7,2 & 7,5 \\
\hline Miristat(C14) & 11,8 & 11,8 & 11,8 & 11,8 & 12,0 \\
\hline Palmitat(C16) & 17,3 & 17,3 & 17,1 & 17,2 & 17,4 \\
\hline Stearat(C18) & 22,6 & 22,6 & 22,5 & 22,6 & 22,8 \\
\hline Oleat(C18:1) & 23,1 & 23,2 & 23,0 & 23,2 & 23,3 \\
\hline Linoleat(C18:2) & 24,3 & 24,3 & 24,2 & 24,3 & 24,4 \\
\hline
\end{tabular}

\section{Waktu Retensi}

Bardasarkan pada asam lemak standar maka waktu retensi untuk masingmasing asam lemak dapat dilihat pada Tabel 1 .

Berdasarkan waktu retensi metil ester asam lemak VCO yang disajikan pada tabel
1, dapat diketahui bahwa waktu retensi untuk masing-masing asam lemak hampir tidak bervariasi dengan pelakuan berbagai metode metilasi VCO tetapi untuk asam kapraot tidak terdeteksi oleh kromatografi gas. Kelima metode di atas menggunakan perlakuan yang berbeda tetapi tidak menunjukkan adanya asam kaproat. 


\section{Luas Puncak}

Luas puncak adalah luas area dibawah puncak. Luas puncak untuk masingmasing asam lemak dalam berbagai metode metilasi dapat dilihat dalam tabel 2 .

Berdasarkan luas puncak metil ester asam lemak VCO yang disajikan pada tabel
2, dapat diketahui bahwa asam linoleat mempunyai luas puncak yang terendah diikuti asam stearat dan asam kaprat. Luas puncak yang tertinggi dihasilkan oleh asam laurat diikuti oleh asam miristat.

Tabel 2. Luas puncak metil ester asam lemak VCO dari berbagai metode

\begin{tabular}{|c|c|c|c|c|c|}
\hline \multirow{3}{*}{ Asam lemak } & \multicolumn{5}{|c|}{ Luas Puncak } \\
\hline & \multicolumn{2}{|c|}{$\begin{array}{l}\text { Transesterifikasi } \\
\text { (Christie, 1993) }\end{array}$} & \multicolumn{2}{|c|}{$\begin{array}{l}\text { Transesterifikasi } \\
\text { (Laureles, 2002) }\end{array}$} & \multirow{2}{*}{$\begin{array}{l}\text { Esterifikasi } \\
\text { (IUPAC, } \\
\text { 1987) }\end{array}$} \\
\hline & Asam & Basa & Asam & Basa & \\
\hline Kaprilat(C8) & 6650 & 2953 & 7610 & 12085 & 30682 \\
\hline $\operatorname{Kaprat}(\mathrm{C} 10)$ & 8989 & 9765 & 8500 & 12952 & 26845 \\
\hline Laurat(C12) & 80617 & 88956 & 69197 & 105582 & 204168 \\
\hline Miristat(C14) & 35230 & 35190 & 27662 & 42898 & 80408 \\
\hline Palmitat(C16) & 19477 & 16917 & 13927 & 21839 & 40470 \\
\hline Stearat(C18) & 5829 & 4914 & 4162 & 6425 & 12889 \\
\hline Oleat(C18:1) & 13672 & 11382 & 9793 & 15594 & 27618 \\
\hline \multirow[t]{2}{*}{ Linoleat $(\mathrm{C} 18: 2)$} & 1918 & 2676 & 2087 & 3370 & 6479 \\
\hline & 172382 & 172753 & 142938 & 220745 & 458655 \\
\hline
\end{tabular}

Tabel 3. Persen puncak area metil ester asam lemak VCO dari berbagai metode

\begin{tabular}{|c|c|c|c|c|c|c|c|}
\hline \multirow{3}{*}{ Asam Lemak } & \multicolumn{6}{|c|}{ Persen (\%) Puncak Area } & \multirow{3}{*}{$\begin{array}{c}\text { Esterifikasi } \\
\text { IUPAC }^{*} \\
(\%)\end{array}$} \\
\hline & \multicolumn{2}{|c|}{$\begin{array}{l}\text { Transesterifikasi } \\
\text { (Christie, 1993) }\end{array}$} & \multicolumn{2}{|c|}{$\begin{array}{l}\text { Transesterifikasi } \\
\text { (Laureles, 2002) }\end{array}$} & \multirow{2}{*}{$\begin{array}{l}\text { Esterifikasi } \\
\text { (IUPAC, } \\
\text { 1987) }\end{array}$} & \multirow[t]{2}{*}{$\mathrm{mg} / \mathrm{g}$} & \\
\hline & Asam & Basa & Asam & Basa & & & \\
\hline Kaprilat(C8) & 3,9 & 1,7 & 5,3 & 5,5 & 7,1 & 247,68 & 24 \\
\hline Kaprat(C10) & 5,2 & 5,7 & 5,9 & 5,9 & 6,2 & 53,99 & 5 \\
\hline Laurat(C12) & 46,8 & 51,5 & 48,4 & 47,8 & 47,5 & 404,45 & 39 \\
\hline Miristat(C14) & 20,8 & 20,4 & 19,4 & 19,4 & 18,7 & 152,62 & 15 \\
\hline Palmitat(C16) & 11,3 & 9,8 & 9,7 & 9,9 & 9,4 & 77,28 & 7 \\
\hline Stearat(C18) & 3,4 & 2,8 & 2,9 & 2,9 & 3,0 & 23,34 & 2 \\
\hline Oleat(C18:1) & 7,9 & 6,6 & 6,9 & 7,1 & 6,4 & 53,51 & 5 \\
\hline \multirow[t]{2}{*}{ Linoleat $(\mathrm{C} 18: 2)$} & 1,1 & 1,5 & 1,5 & 1,5 & 1,5 & 17,63 & 2 \\
\hline & 100 & 100 & 100 & 100 & 100 & 1030,5 & 100 \\
\hline
\end{tabular}

Ket : * Dihitung berdasarkan pada standar internal dari standar asam-asam lemak.

\section{Persen Luas Puncak}

Persen luas puncak adalah perbandingan antara masing-masing puncak area terhadap total luas puncak. Persen puncak area untuk masing-masing asam lemak dapat dilihat dalam tabel 3.
Persen luas puncak yang tertinggi dihasilkan oleh asam laurat yaitu bervariasi dari $46,8 \%-51,5 \%$ dan persen luas puncak yang terendah dihasilkan oleh asam linoleat yaitu bervariasi yaitu dari $1,1 \%-1,5 \%$.

Asam kaprilat merupakan asam lemak rantai pendek yang mudah menguap dan mudah larut dalam air, rendahnya 
komposisi asam kaprilat yang diperoleh dengan metode Christie, menunjukkan bahwa metode ini relatif kurang baik. Pada metode esterifikasi IUPAC diperoleh komposisi asam kaprilat yang lebih tinggi $(7,1 \%)$.

Dari tabel di atas terlihat bahwa variasi tertinggi persen puncak area yang dihasilkan oleh asam kaprilat yaitu dari 1,7\% - 7,1 \% tetapi untuk asam kaproat tidak terdeteksi oleh kromatografi gas, dari kelima metode yang digunakan.

Persen luas puncak asam kaprilat yang tertinggi diperoleh pada metode metilasi esterifikasi IUPAC yaitu 7,1\%. Pada metode metilasi Christie menggunakan katalis asam diperoleh puncak area asam kaprilat yang lebih rendah $(3,9 \%)$ dibandingkan dengan metode metilasi Laureles menggunakan katalis asam $(5,3 \%)$ dan metode esterifikasi IUPAC $(7,1 \%)$.

Persen luas puncak asam kaprilat yang diperoleh pada metode metilasi Christie menggunakan katalis basa lebih rendah $(1,7$ $\%)$ dibandingkan metode metilasi Laureles menggunakan katalis basa $(5,5 \%)$.

Pada metode transesterifikasi dengan katalis asam $\left(\mathrm{H}_{2} \mathrm{SO}_{4}\right)$ untuk waktu reaksi yang lama perlu ditambahkan jumlah alkohol (Christie, 1993). Metode ini dapat berlangsung pada suhu di atas $100{ }^{\circ} \mathrm{C}$ dengan 3 sampai 48 jam reaksi kecuali jika reaksi dilakukan pada suhu dan tekanan tinggi, disamping itu juga metode ini dapat digunakan untuk minyak yang bermutu rendah atau memiliki kandungan asam lemak bebas tinggi (Mardiah et al., 2004 ).

Menurut Christie (1993) bahwa metode esterifikasi yang baik untuk asamasam lemak rantai pendek adalah pemanasan dengan bahan reaksi dan keterlibatan air dalam ekstraksi harus dihindarkan karena asam lemak tersebut mudah menguap dan mudah larut dalam air.

Metode transesterifikasi dengan katalis basa (sodium metoksida) mempercepat reaksi. Dalam metode ini menggunakan alkohol dalam jumlah yang banyak dan pada saat reaksi berlangsung tidak boleh ada air. Reaksinya dapat berlangsung 1 hingga 2 jam pada suhu ruang dan akan efisien jika digunakan untuk minyak yang bermutu tinggi atau kandungan asam lemak bebasnya sangat rendah, karena dengan adanya sedikit kandungan asam lemak bebas dan air dalam reaktan akan menyebabkan terbentuknya sabun sehingga menurunkan hasil ester dan mempersulit pemisahan ester dengan gliserol (Mardiah $e t$ al., 2004 ).

Persen luas puncak asam kaprilat yang diperoleh pada metode esterifikasi IUPAC cukup tinggi dengan jumlah 7,1\%. Hal ini disebabkan karena $\mathrm{BF}_{3}$-metanol merupakan asam lewis dalam wujud koordinasi kompleks dengan metanol menjadikannya sebagai katalis asam yang kuat (Christie, 1993). Dalam reaksinya pemanasan yang digunakan tidak lama yaitu pada pemanasan pertama selama 5 menit dan pemanasan kedua selama 25 menit sehingga dapat memperkecil menguapnya asam lemak rantai pendek dan tidak menggunakan air untuk mengekstraksi sehingga asam kaprilat yang diperoleh cukup tinggi.

Persen luas puncak asam kaprilat yang diperoleh pada metode metilasi Laureles menggunakan katalis asam dan basa adalah $5,3 \%$ dan 5,5\%. Pada metode ini tidak menggunakan pemanasan yang terlalu lama, yaitu pemanasan yang digunakan hanya 1 menit sehingga hilangnya asam lemak rantai kaprilat masih bisa dihindari dan pada tahap reaksi ini tidak menggunakan air untuk mengekstraksi. Menurut Christie (1993) bahwa pada tahap akhir dari reaksi transesterifikasi basa ditambahkan asam $\left(\mathrm{H}_{2} \mathrm{SO}_{4}\right)$ hal ini bertujuan untuk memperkecil terjadinya reaksi hidrolisis.

Persen luas puncak asam kaprilat yang diperoleh pada metode metilasi Christie menggunakan katalis asam dan basa adalah sangat rendah yaitu $3,9 \%$ dan $1,7 \%$. Asam kaprilat merupakan asam lemak rantai pendek yang mudah menguap selama proses transesterifikasi dimana dalam hal ini digunakan waktu refluks yang lama yaitu 10 jam dan pada saat diekstraksi dengan air asam lemak ini mudah larut dalam air. Hal ini menyebabkan asam kaprilat yang diperoleh sangat rendah.

Kelima metode yang digunakan yaitu transesterifikasi asam dan basa (Christie, 1993), transesterifikasi asam dan basa (Laureles, 2002) dan esterifikasi (IUPAC, 1987) menggunakan perlakuan yang berbeda tetapi tidak menunjukkan adanya asam kaproat. Hal ini disebabkan karena asam kaproat merupakan asam lemak rantai pendek yang mudah menguap dan cenderung mudah larut dalam air, sehingga pada setiap 
perlakuan yang digunakan yaitu pada waktu pemanasan dan pada waktu diekstraksi dengan air dapat menghilangkan komposisi asam kaproat yang juga relatif sangat sedikit dalam minyak kalapa.

\section{KESIMPULAN}

1. Kelima metode esterifikasi yang digunakan untuk analisa komposisi asam lemak dari VCO menunjukkan hasil yang berbeda-beda.

2. Kaproat tidak dapat terdektesi dengan kromatografi gas dari kelima metode esterifikasi yang digunakan.

3. Metode esterifikasi (IUPAC, 1987), lebih baik dari metode Christie dan Laureles dalam menganalisa asam lemak rantai pendek seperti asam kaprilat.

\section{DAFTAR PUSTAKA}

Anonim. 2004. APCC Standards for Virgin Coconut Oil. www.apccsec.org/ document [17 Maret 2006]

Christie, W.W. 1993. Preparation of Ester Derivates of Fatty Acids for Chromatography Analysis. Advance in Lipid Methodology. Ed. W. W. Christie. Oily Press. Dundee, Scotland.

Gaman, P.M. And K.B. Sherrington. 1994. Pengantar Ilmu Pangan Nutrisi dan Mikrobiologi. Gadjah Mada University Press, Yogyakarta.

Hendayana, S., A. Kadarohman, AA. Sumarna, A. Supriana. 1994. Kimia Analitik Instrumen. IKIP Semarang Press, Semarang.

IUPAC. 1987. Standard Methods for the Analysis of oils, fats and Derivates $7^{\text {th }}$ Edition. International Union of Pure and Aplied Chemistry, Consorsium on oils, Fats and Derivates. Backwell Scientificts Publication Oxford, England.

Ketaren, S. 1986. Pengantar Teknologi Minyak dan Lemak Pangan. UI Press, Jakarta.

Khopkar, S. M. 1990. Konsep Dasar Kimia Analitik. UI Press, Jakarta.
Laureles, L. R., F. M. Rodriguez., C. E. Reano., G. A. Santos., A. C. Laurena., E. M. T. Mendoza. 2002. Variability in Fatty ACID and Triacilglycerol Composition of the Oil of Coconut (Coconus nucifera L.) Hybrids and Their Parentals. J. Agric. Food Chem. 50 : 1581-1586

Mardiah., A. Widodo., E. Trisningwati., A. Purijatmiko. 2004. Pengaruh Asam Lemak Dan Konsentrasi Katalis Asam Terhadap Karakteristik Dan Konversi Biodiesel Pada Transesterifikasi Minyak Mentah Dedak Padi. ITS.

http://www.kemahasiswaan.its.ac.ad/files/PK MI [17 Maret 2006]

Sastrohamidjojo, H. 2005. Kimia Organik. Gadjah Mada University Press, Yogyakarta.

Sutarmi., H. Rozaline. 2005. Taklukkan Penyakit Dengan VCO. Penebar Swadaya, Jakarta.

Winarno, F.G. 2002. Kimia Pangan dan Gizi. PT. Gramedia Pustaka Utama, Jakarta.

Zapsalis, C., R. Beck. 1986. Food Chemistry and Nutritional Biochemistry. Macmillan Publishing Company, New York. 